\title{
Association of Glycemic Indexes, Hyposalivation, and Xerostomia Type 1 Diabetic Patients
}

\author{
Asociación de los Índices de Glucemia, Hiposalivación \\ y Xerostomía en Pacientes Diabéticos Tipo 1
}

\begin{abstract}
Kesly Mary Ribeiro Andrades*; Gustavo Bento de Oliveira*; Lúcia Fátima de Castro Àvila*; Marin de Los Rios Odebrecht ${ }^{\star * * *}$ \& Luiz Carlos Machado Miguel ${ }^{*}$
\end{abstract}

\begin{abstract}
ANDRADES, K. M. R.; OLIVEIRA, G. B.; ÁVILA, L. F. C.; ODEBRECHT, M. R. \& MIGUEL, L. C. M. Association of glycemic indexes, hyposalivation, and xerostomia type 1 diabetic patients. Int. J. Odontostomat., 5(2):185-190, 2011.

ABSTRACT: The aim of this study was to assess the relationship between glycemic control of type 1 diabetic (DM1) patients and hyposalivation and xerostomia. This observational transversal study used a quantitative approach with a sample of 25 DM1 patients enrolled at the Diabetes Association of Joinville (ADIJO) in 2008. Variables assessed were sialometry through stimulated salivary flow, complaints of xerostomia, and testing for glycemic control: fasting capillary glycemia (FCG) and glycated hemoglobin $(\mathrm{HbA} 1 \mathrm{c})$. The Mann-Whitney $U$ test, chi-square test, and Fisher's exact test were used to verify a possible association among the variables. Most subjects $(64 \% ; 16 / 25)$ showed concomitant hyposalivation and xerostomia. No significant statistical difference between glycemic control (FCG and HbA1c), hyposalivation, and xerostomia ( $p=0.54$ ) was found. A high prevalence of hyposalivation and xerostomia was found to be more closely related to higher FCG values at the moment of blood testing than to higher values of $\mathrm{HbA} 1 \mathrm{c}$.
\end{abstract}

KEY WORDS: diabetes Mellitus, dry mouth, dental treatment.

\section{INTRODUCTION}

Diabetes mellitus (DM) is a chronic metabolic disorder characterized by hyperglycemia and resulting in either lack or relative insufficiency of insulin. It is caused by the low insulin production of the pancreas or the lack of response of the peripheral tissues to the hormone.

The insulin regulates the carbohydrate metabolism, and its absence causes a reduction of blood glucose entering cells, consequently increasing its blood level, characterizing the hyperglycemia state (Costa et al., 2004; Faulconbridge et al., 1981). Hyperglycemia, glycosuria, polyuria, polydipsia, and polyphagia are the specific symptoms of the decompensated diabetic patient (Schneider et al., 1995).

The two most common DM manifestations are: type 1 (DM1) and type 2 (DM2). DM1 affects subjects under 25 years-old, approximately $10 \%$ of diabetic patients. Reacting to a total absence of insulin, the body produces an autoimmune reaction that progressively destroys the pancreatic cells responsible for insulin production. DM2 is more common in adults, many of whom are obese. These patients have a resistance to insulin (Mealey et al., 2006; Souza et al., 2003).

The most often used tests for evaluating the degree of DM glycemic control are the glycated hemoglobin $(\mathrm{HbA} 1 \mathrm{c})$ test, which expresses the mean glycemic level for two to three months, and the fasting capillary glycemia test (FCG), carried out for daily monitoring (Lauda et al., 1998; Moimaz et al., 2000).

In addition to the systemic alterations, oral manifestations of DM have been reported, such as xerostomia and/or hyposalivation, alterations in taste, a volume increase of salivary glandules (mainly the parotids), caries, gingivitis, periodontal disease, fungal infections, oral liken planus, tooth loss, odontogenic abscesses, soft tissue lesions, coated tongue, fissured

* Professor (a), Universidade da Região de Joinville, UNIVILLE, Brazil.

* Cirurgião Dentista, Universidade da Região de Joinville, UNIVILLE, Brazil.

*** Professora, Universidade do Vale do Itajaí, UNIVALI, Brazil. 
tongue, and geographic tongue (benign migratory glossitis) (Faulconbridge et al.; Bernick et al., 1975; Fontanini et al., 2004; Lin et al., 2002; Sreebny et al., 1992).

The metabolic control in DM1 patients, mainly in children and teenagers, is a challenge for health professionals (Silverstein et al., 2005). Inappropriate metabolic control in DM patients may result in salivary hypofunction, resulting in hyposalivation and/or xerostomia (Siudikiene et al., 2006).

Xerostomia is the subjective sensation of dry mouth, a symptom reported by the patient (Guggenheimer et al., 2003; Moore et al., 2001). It may be the result of a salivary secretion decrease or it may occur in the presence of a normal salivary production (Guggenheimer et al.). Xerostomia is present in 40 to $60 \%$ of diabetic patients presenting a poor control of the disease, due to the small degree of the salivary production stimulus by the parotid glandule, compared to patients who are able to control the disease and normal subjects (Lalla \& D'Ambrosio, 2001).

Hyposalivation in decompensated DM patients is explained by the increase of diuresis or polyuria, which may affect saliva production (Wollner, 2003). On the other hand, since xerostomia is considered to be a subjective sensation of dry mouth, it may or may not be attributed to the decrease or interruption of the function of salivary glandules. Xerostomia not only presents physical but also psychological and social consequences (Carda et al., 2006).

Xerostomia and hyposalivation might be manifestations present in DM1 patients with inadequate glycemic control. However, these manifestations may also be related to neuropathy (Amaral et al., 2006; Chaves et al., 2000; Feio \& Sapeta, 2005; Moore et al.; Tárzia, 1993).

The aim of this study was to assess whether glycemic control, salivary flow and xerostomia have a relationship to DM1 patients.

\section{MATERIAL AND METHOD}

This was an observational, transversal, quantitative study with a sample of 25 type 1 diabetic patients in a population of $57 \mathrm{DM} 1$ patients enrolled at the Diabetes Association of Joinvile (ADIJO) in 2008.
This study was approved by the Ethics Committee in Research on Human Beings of UNIVILLE under number 008/07.

Patients and/or their legal guardians signed a free and clarified consent form to participate in the study, which involved a clinical examination and hematologic tests for glycemic control assessment (HbA1c and FCG). Patient personal data, time elapsed since DM diagnosis, presence of other systemic diseases and use of medicines were recorded.

The following patients were excluded: syndromic patients, pregnant women, and subjects on medication presenting hyposalivation as a side effect. All patients used insulin for diabetes control and did not take oral hypoglicemiants.

Xerostomia assessment was performed using a questionnaire composed of the following questions: 1. Do you feel a burning sensation in any part of your mouth? ; 2 . Do you feel your mouth getting dry during the day?; and 3 . Do you notice any alteration in taste? Patients were classified as xerostomic when they answered yes to any of the questions (Moore et al.). The $\mathrm{HbA} 1 \mathrm{c}$ dosage was carried out in a single clinical laboratory analysis. DM1 was considered as not under control when subjects presented reference values above $7 \%$ of $\mathrm{HbA} 1 \mathrm{c}$ and DM1 was considered as under control when subjects presented reference values below or equal to $7 \%$.

Patients with FCG values greater than $100 \mathrm{mg} /$ dl were considered to be hyperglycemic; those with values between 80 and $100 \mathrm{mg} / \mathrm{dl}$ were considered to be normoglycemic.

After blood samples were collected, all participants underwent sialometry, stimulating salivary flow by chewing a $1.5 \mathrm{~cm}$ sterilized rubber gum for 6 minutes. The saliva collected during the first minute was discarded and the rest was collected in a sterilized and cold, graduated test tube. Values lower than $0.7 \mathrm{ml} / \mathrm{min}$ were considered hyposalivation.

Next, the patients answered the questionnaire on xerostomia. Data were submitted to statistical analysis to assess a possible association between glycemic control, salivary flow, and xerostomia, using non-parametric Mann-Whitney $U$ test, chi-square test, and Fisher's exact test. Statistically significant values were set at $5 \%(p<0.05)$. 


\section{RESULTS}

In the sample of 25 DM1 patients, 48\% (12/25) were female and $52 \%(13 / 25)$ were male; age range was: $0-11,24 \%(6 / 25) ; 12-17,24 \%(6 / 25)$ and above $18,52 \%(13 / 25)$ (Table I). All patients had been diagnosed more than 5 years before this study took place (Table I).

Table I. Sample data. Salivary flow mean was $0.63 \pm 0.44 \mathrm{ml} /$ $\min$.

\begin{tabular}{lccccc}
\hline & \multicolumn{2}{c}{ Sex } & \multicolumn{3}{c}{ Age range } \\
\cline { 2 - 6 } & $\mathrm{M}$ & $\mathrm{F}$ & $0-11$ & $12-17$ & $>18$ \\
\cline { 2 - 6 } $\mathrm{f}$ & 13 & 12 & 6 & 6 & 13 \\
$\mathrm{f} \%$ & 52 & 48 & 24 & 24 & 52 \\
\hline
\end{tabular}

The stimulated sialometry showed that 17 patients $(68 \%)$ presented values lower than $0.7 \mathrm{ml} / \mathrm{min}$, and they also reported xerostomia symptoms in the questionnaire.

Concerning HbA1c tests, $84 \%(21 / 25)$ of the patients showed values higher than $7 \%$, meaning the disease was not under control. Sixteen percent (4/25) showed values lower or equal to $7 \%$, indicating the disease was under control (Table II). $\mathrm{HbA} 1 \mathrm{c}$ mean was $9.977 \pm 1.936$, thus demonstrating that most of the patients were decompensated.

Fasting capillary glycemia (FCG) showed that $80 \%(20 / 25)$ of the patients presented values higher than normal $(100 \mathrm{mg} / \mathrm{dl})$ and only $20 \%(5 / 25)$ presented values lower than $100 \mathrm{mg} / \mathrm{ml}$ (Table II).

Table II. Salivary flow, xerostomia, and glycemic control. Source: study data.

\begin{tabular}{|c|c|c|c|c|c|c|c|c|}
\hline \multirow[t]{2}{*}{ Patient } & \multicolumn{2}{|c|}{ Salivary flow } & \multirow[t]{2}{*}{ Xerostomia } & \multicolumn{2}{|c|}{ HbA1c } & \multicolumn{3}{|c|}{ FCG $-\mathrm{mg} / \mathrm{dl}$} \\
\hline & $\mathrm{ml} / \mathrm{min}$ & Hyposalivation & & $<7 \%$ & $>7 \%$ & $<100$ & 101 to 300 & 301 to 450 \\
\hline 1 & 1.6 & & & & $x$ & & $x$ & \\
\hline 2 & 0.4 & $x$ & $x$ & & $x$ & & $x$ & \\
\hline 3 & 0.4 & $\mathrm{x}$ & $x$ & & $x$ & & & $\mathrm{x}$ \\
\hline 4 & 0.22 & $x$ & $x$ & & $x$ & & $x$ & \\
\hline 5 & 0.6 & $x$ & $x$ & & $x$ & & $x$ & \\
\hline 6 & 1.4 & & & & $x$ & & $x$ & \\
\hline 7 & 0.16 & $x$ & $x$ & & $x$ & & & $x$ \\
\hline 8 & 0.6 & $x$ & $x$ & & $x$ & & $x$ & \\
\hline 9 & 0.18 & $x$ & $x$ & & $x$ & & & $x$ \\
\hline 10 & 0.2 & $x$ & $x$ & & $x$ & $x$ & & \\
\hline 11 & 1.0 & & & & $x$ & & $x$ & \\
\hline 12 & 1.0 & & & & $x$ & & $x$ & \\
\hline 13 & 1.18 & & & & $x$ & $x$ & & \\
\hline 14 & 0.18 & $x$ & $x$ & & $x$ & & & $x$ \\
\hline 15 & 0.22 & $x$ & $x$ & & $x$ & & & $x$ \\
\hline 16 & 0.38 & $x$ & $x$ & $x$ & & $x$ & & \\
\hline 17 & 0.5 & $x$ & $x$ & & $x$ & & $x$ & \\
\hline 18 & 0.01 & $x$ & $x$ & & $x$ & & $x$ & \\
\hline 19 & 0.38 & $x$ & $x$ & $x$ & & & $x$ & \\
\hline 20 & 0.9 & & & & $x$ & $x$ & & \\
\hline 21 & 1.2 & & & $x$ & & & $x$ & \\
\hline 22 & 0.6 & $x$ & $x$ & & $x$ & & $x$ & \\
\hline 23 & 1.02 & & & & $x$ & & & $x$ \\
\hline 24 & 0.4 & $x$ & $x$ & $x$ & & $x$ & & \\
\hline 25 & 1.0 & & & & $x$ & & $x$ & \\
\hline Total & & 16 & 16 & 4 & 21 & 5 & 14 & 6 \\
\hline
\end{tabular}


Assessment of the association between $\mathrm{HbA} 1 \mathrm{c}$, hyposalivation, and xerostomia variables showed no statistically significant differences $(p=0.57)$.

The association between FCG, hyposalivation, and xerostomia failed to show statistically significant differences.

\section{DISCUSSION}

A large number of studies have been carried out on oral complications in DM1 patients; however, comparing the outcomes is very difficult because there is a wide variety of criteria for sample selection and study design.

Several researchers were able to show a relationship between xerostomia and/or hyposalivation and the presence of DM (Sreebny et al.; Fontanini et al.; Moore et al.; Carda et al.). Most of these studies were done with DM2 patients who were taking medication with side effects such as salivary flow reduction; consequently, it seems difficult to affirm that this association occurred.

In this study on DM1 patients, without the use of xerostomic medication, there was a high prevalence $(64 \%, 16 / 25)$ of patients who reported xerostomia. This value was a little higher than that of a study which observed that xerostomia was present in 40 to $60 \%$ of the decompensated diabetic patients (Lalla \& D'Ambrosio). The patients reporting xerostomia also concomitantly showed hyposalivation.

A study evaluating stimulated and non-stimulated salivary flow in diabetic patients found that hyposalivation was not related to the patient's poor glycemic control
(Dodds \& Dodds, 1997). Based on statistical tests, we discovered a similar result: FCG and $\mathrm{HbA} 1 \mathrm{c}$ values showed a dependent relationship with the salivary flow, without a statistically significant difference. However, of the 16 subjects presenting hyposalivation and xerostomia, $15(93.75 \%)$ showed a FCG value higher than $100 \mathrm{ml} / \mathrm{dl}$ at the time a blood sample was collected. Moreover, critically low values of sialometry were observed in patients presenting FCG between 301 and $450 \mathrm{mg} / \mathrm{dl}$. This finding has clinical significance because hyposalivation has been associated with a high blood glucose concentration in decompensated DM subjects. Consequently, in these patients, the body needs to mobilize the water to dilute the high blood glucose concentration. Hyperglycemia is also characterized by signs of polyuria and polydipsia, and may cause dry mouth sensation.

Studies reported that the reduction of salivary flow was directly associated with DM patients poor metabolic control, while hyposalivation and xerostomia were related to high values of HbA1c and FCG (Lalla \& D'Ambrosio; Luguetti et al., 1999; Korn et al., 2005). Poor metabolic control prevalence in Brazilian adolescents was $76 \%$ (Saes Busato et al., 2010) which is similar to our findings, demonstrating that maintaining metabolic control during adolescence is complex. Our study found clinical results similar to those of the aforementioned studies. However, the small sample number could account for the statistical insignificance of this association. Of the patients considered decompensated by $\mathrm{HbA} 1 \mathrm{c}$ assessment, only $33 \%(7 / 21)$ did not show xerostomia and hyposalivation.

In conclusion, according to results from the sample studied, one can conclude that hyposalivation and xerostomia were more often prevalent in DM1 patients and were associated with higher FCG values at the time a blood test was conducted than to higher values of $\mathrm{HbA} 1 \mathrm{c}$.

ANDRADES, K. M. R.; OLIVEIRA, G. B.; ÁVILA, L. F. C.; ODEBRECHT, M. R. \& MIGUEL, L. C. M. Asociación de los índices de glucemia, hiposalivación y xerostomía en pacientes diabéticos tipo 1. Int. J. Odontostomat., 5(2):185-190, 2011.

RESUMEN: El objetivo de este estudio fue evaluar la relación entre el control glucémico de los pacientes diabéticos tipo 1 (DM1) e hiposalivación y xerostomía. Este estudio observacional de cohorte transversal utilizó un enfoque cuantitativo con una muestra de 25 pacientes con DM1 inscritos en la Asociación de Diabetes de Joinville (ADIJO) el 2008. Las variables evaluadas fueron sialometría a través del flujo salival estimulado, quejas de la xerostomía, y las pruebas para el control glucémico: glucosa capilar en ayunas (GCA) y hemoglobina glicosilada ( $\mathrm{HbA1c}$ ). Se utilizaron las pruebas de Mann-Whitney, chi-cuadrado y exacta de Fisher para verificar una posible asociación entre las variables. La mayoría de los sujetos (64\%, 16/25) mostró hiposalivación concomitante y xerostomía. No se observaron diferencias estadísticamente significativas entre el control glucémico (GCA y HbA1c), hiposalivación y xerostomía $(p=0,54)$. Una alta prevalencia de hiposalivación y xerostomía se encontró estrechamente relacionada con los valores altos de GCA mas que con valores altos de HbA1c en el momento del análisis sanguíneo.

PALABRAS CLAVE: diabetes mellitus, boca seca, tratamiento dental. 


\section{REFERENCES}

Amaral, F. F.; Ramos, P. G. \& Ferreira, S. R. Estudo da frequência de cárie e fatores associados no diabetes mellitus tipo 1. Arq. Bras. Endocrinol Metab., 50(3):515-22, 2006.

Bernick, S. M.; Cohen, D. W.; Baker, L. \& Laster, L. Dental disease in children with diabetes mellitus. $J$. Periodontol., 46(4):241-5, 1975.

Carda, C.; Mosquera-Lloreda, N.; Salom, L.; Gomez de Ferraris, M. E. \& Peydró, A. Structural and functional salivary disorders in type 2 diabetic patients. Med. Oral Patol. Oral Cir. Bucal, 11(4):E309-14,2006.

Chaves, E. M.; Taylor, E. W.; Borrel, L. N. \& Ship, J. Á. Salivary Function and glycemic control in older person with diabetes. Oral Surg. Oral Med. Oral Pathol. Radiol Endod., 89(3):305-11, 2000.

Costa, C. C.; Resende, G. B.; Souza, J. M.; Tavares, S. S.; Almeida, I. C. S. S. \& Filho, L.C.C. Estudo das manifestações bucais em crianças com diabetes e suas variáveis de correlação. Arq. Bras. Endocrinol. Metab., 48(3):374-8,2004.

Dodds, M. W. \& Dodds, A. P. Effects of glycemic control on saliva flow rates and protein composition in noninsulin-dependent diabetes mellitus. Oral Surg. Oral Med. Oral Pathol. Oral Radiol. Endod., 83(4):46570, 1997.

Faulconbridge, A. R.; Bradshaw, W. C.; Jenkins, P. A. \& Baum, J. D. The dental status of a group of diabetic children. Br. Dent. J., 151(8):253-5, 1981.

Feio, M. \& Sapeta, P. Xerostomia em Cuidados Paliativos. Acta Med. Port., 18(6):459-66,2005.

Fontanini, C. R. R. Avaliação Estomatológica de Pacientes Portadores de Diabetes Melito, Usuários de Insulina e não Usuários de Insulina. Tese, Faculdade de Odontologia, Universidade do Vale do Rio Verde de Três Corações, 2004.

Guggenheimer, J. \& Moore, P. A. Xerostomia: etiology, recognition and treatment. J. Am. Dent. Assoc., 134(1):61-9; quiz 118-9, 2003.

Korn, G. P.; Pupo, D. B.; Quedas, A. \& Bussoloti Filho, I. Correlação entre o grau de Xerostomia e resultado de sialometria em pacientes com síndrome de Sjögren. Rev. Bras. Ortorrinolaringol., 68(5):624-8, 2005.

Lalla, R. V. \& D'Ambrosio, J. A. Dental management considerations for the patient with diabetes mellitus. J. Am. Dent. Assoc., 132(10):1425-32, 2001.

Lauda, P. A.; Silveira, B. L. \& Guimarães, M. B. Manejo odontológico do paciente diabético. J. Bras. Odontol., 2:81-7, 1998.

Lin, C. C.; Sun, S. S.; Kao, A. \& Lee, C. C. Impaired salivary function in patients with noninsulindependent diabetes mellitus with xerostomia. J. Diabetes Complications, 16(2):176-9, 2002.

Lughetti, L.; Marino, R.; Bertolani, M. F. \& Bernasconi, $\mathrm{S}$. Oral health in children and adolescents with IDDM-a review. J. Pediatr. Endocrinol. Metab., 12(5 Suppl 2):603-10, 1999.

Mealey, B. L.; Oates, T. W. \& American Academy of Periodontology. Diabetes mellitus and periodontal diseases. J. Periodontol., 77(8):1289-303, 2006.

Moimaz, S. A. S.; Saliba, C. A.; Arcieri, R. M.; Saliba, T. A. \& Ramos, A. P. P. Estado da saúde, hábitos e conhecimentos de crianças e jovens diabéticos. ROBRAC, 9(27):50-3, 2000.

Moore, P. A.; Guggenheimer, J.; Etzel, K. R.; Weyant, R. J. \& Orchard, T. Type 1 diabetes mellitus, xerostomia, and salivary flow rates. Oral Surg. Oral Med. Oral Pathol. Oral Radiol. Endod., 92(3):28191, 2001.

Saes Busato, I. M.; Bittencourt, M. S.; Machado, M. A.; Grégio, A. M. \& Azevedo-Alanis, L. R. Association between metabolic control and oral health in adolescents with type 1 diabetes mellitus. Oral Surg. Oral Med. Oral Pathol. Oral Radiol. Endod., 109(3):e51-6, 2010.

Schneider, M.; Bernd, G. \& Nurkim, N. L. Diabetes Mellitus e suas manifestações sobre o periodonto: uma revisão bibliográfica. Revista Odonto Ciência, 10(20):89-98, 1995.

Silverstein, J.; Klingensmith, G.; Copeland, K.; Plotnick, L.; Kaufman, F.; Laffel, L.; Deeb, L.; Grey, M.; Anderson, B.; Holzmeister, L. A.; Clark, N. \& American Diabetes Association. Care of children 
ANDRADES, K. M. R.; OLIVEIRA, G. B.; ÁVILA, L. F. C.; ODEBRECHT, M. R. \& MIGUEL, L. C. M. Association of Glycemic indexes, hyposalivation, and xerostomia type 1 diabetic patients. Int. J. Odontostomat., 5(2):185-190, 2011.

and adolescents with type 1 diabetes: a statement of the American Diabetes Association. Diabetes Care, 28(1):186-212, 2005.

Siudikiene, J.; Machiulskiene, V.; Nyvad, B.; Tenovuo, J. \& Nedzelskiene, I. Dental caries and salivary status in children with type 1 diabetes mellitus, related to the metabolic control of the disease. Eur. J. Oral Sci., 114(1):8-14, 2006.

Souza, R. R.; Castro, R. D. \& Silva, S. C. O paciente odontológico portador de diabetes Mellitus: Uma revisão da literatura. Pesq. Brás. Odontop. Clin. Integr., 3(2):71-7, 2003.

Sreebny, L. M.; Yu, A.; Green, A. \& Valdini, A. Xerostomia in diabetes mellitus. Diabetes Care, 15(7):900-4, 1992.

Tárzia, O. Importância do fluxo salivar com relação à saúde bucal. Cecade News, 1(3/4):13-7,1993.

Wollner, D. Oral implications of diabetes mellitus. Pac. Health Dialog., 10(1):98-101, 2003.
Correspondence to:

Professora MSc. Kesly Mary Ribeiro Andrades

Universidade da Região de Joinville

UNIVILLE

Brasil

Email keslyribeiro@hotmail.com.br

Received: 10-06-2011

Accepted: 16-07-2011 